\title{
Monitoring and modeling of urban sprawl through remote sensing and GIS in Kuala Lumpur, Malaysia
}

\author{
Mukesh Singh Boori ${ }^{1,23^{*}}$, Maik Netzband ${ }^{2}$, Komal Choudhary ${ }^{1}$ and Vít Voženílek
}

\begin{abstract}
Introduction: Kuala Lumpur is currently experiencing a large-scale urban transformation. This study explores a multi-buffer ring method to investigate the spatial and temporal dynamics of urban growth in the Kuala Lumpur metropolitan area by using Geographical Information Systems (GIS) and remote sensing imageries from1989 to 2014.

Methods: The first Landsat images from 1989, 2001, and 2014 were classified with maximum likelihood classification to produce land cover maps and identify four types of land cover: urban/built-up, agriculture, forest, and water. Then, the area coverage for all the land use types at different points in time were measured and combined with distance from the city center. Later on, urbanization densities from the city center to the outside for every 1-km distance from 1 to $50 \mathrm{~km}$ are calculated.

Results: City density on the distance of 5, 8, 15, 20, and $30 \mathrm{~km}$ was very high in the years 1989 and 2014. Temporally, urban expansion shows fast and slow growth stages with high-speed growth shifting to the east side of the city.

Conclusions: In general, the population, traffic conditions, industrialization, and policy are the major factors thatinfluenced the urban expansion
\end{abstract}

Keywords: Urbanization; Landsat; Change detection; Remote Sensing; GIS

\section{Introduction}

Kuala Lumpur is one of the most important historical, cultural, industrial, and commercial cities in Malaysia as well as one of the most important cities in Asia. It has a booming economy with dynamic growth. During the last three decades, growth in population, industry, and economic activities has been strongly concentrated in the Kuala Lumpur metropolitan area. Formed in the 1850s, the Federal Territory of Kuala Lumpur is the national capital of Malaysia. The city has an estimated population of 1.627 million (2010 census). Malaysia's rich and diverse urban history developed primarily from the second half of the twentieth century when it shifted from a largely rural to a largely urban population. Following independence in 1957 and the formation of Malaysia in 1963, Kuala Lumpur became the administrative center and took center stage in national development. From the mid-1980s, Kuala Lumpur underwent policy

\footnotetext{
* Correspondence: msboori@gmail.com

${ }^{1}$ Palacky University Olomouc, 17. listopadu 50, 77146 Olomouc, Czech Republic

${ }^{2}$ Geographical Institute, Ruhr University Bochum, Bochum, Germany Full list of author information is available at the end of the article
}

shifts, notably privatization and economic liberalization (Malaysia 1991). Major development and supporting policy shifts were undertaken, and within two decades, there were major transformations and dramatic landscape changes in Kuala Lumpur (Saboori et al. 2012).

In the mid-1980s, there was a gradual but obvious change in the nature of the Malaysian economy, as was examined earlier. In 1987, for instance, the agricultural sector share in GDP was exceeded by the share of the manufacturing sector. In 1990, the agricultural share was $19.4 \%$ compared with $26.6 \%$ for the manufacturing sector (Saboori et al. 2012). Thus, there has been a change in the structure of Malaysia from an agricultural base to a manufacturing base since 1987. This, indeed, marks a milestone in the country's transition towards an industrializing economy (Malaysia 1991). It has often been argued that the process of urbanization and urban growth in the third world has taken place with the expansion of the industrial sector. That is true to a large extent in that, even without a substantial industrial base prior to 1957, Malaysia had experienced a large increase in its urban population. However, with the 
growth of manufacturing since 1957, the impact on the process of urbanization and urban growth has been most tangible as the employment opportunities generated were located in the urban areas (Salari et al. 2013; Boori and Vozenilek 2014). These issues make the necessity to the study of urbanization in Kuala Lumpur.

The Kuala Lumpur Structure Plan 2020 indicates that the population base is set to increase from 1.4 million to 2.2 million over the next 20 years, and that optimizing limited land resources will be a priority. The new Kuala Lumpur 2020 Strategy Plan was undertaken in the early 2000s to revise the 1984 Kuala Lumpur Structure Plan and to cope with the unprecedented growth and changes in the urban landscape. It is made compulsory to study Kuala Lumpur urban growth. Urbanization has been traditionally understood using the frameworks of demography, urban planning, urban infrastructure, transportation, affordable housing, and urban development (Yin et al. 2011; Boori et al 2014a). Urban growth is characterized by significant gains in urban/built-up areas at the expense of green or open spaces. In this study, the urban/built-up land cover class is defined as the areas dominated by buildings, asphalt, and concrete, including residential, commercial, industrial, and transportation space (Yin et al. 2011; Boori and Vozenilek 2014; Salari et al. 2013). Other types of urban land use, such as golf courses and urban green parks are not included in the urban/built-up class. Urbanization studies are useful to planners who seek to avoid the irreversible and cumulative effects of urban growth and to optimize the allocation of urban services (Dewan and Yamaguchi 2009a; Barnsley and Barr 1996; Boori et al. 2014b, Thinh et al. 2013). Furthermore, such information is indispensable for the assessment and evaluation of sustainable urban and environmental planning strategies (Wu and Hao 2012; Alphan 2003; Jensen and Im 2007). Land use planning is an integral part of the viability and liveability of a metropolitan area because it affects decisions about where and how we live. Over the last few decades, government agencies and local councils in different countries have been continually developing and adopting land use planning strategies to contain and manage urban growth (Yin et al. 2011). For example, "Smart Growth" in the USA and the "compact city" and "intensification" in Europe were devised and adopted to regulate and contain urban sprawl. There are few other studies such as Yagoub (2004) who focused his attention on Al-Ain in the United Arab Emirates. In another study, Al-Awadhi (2007) used available maps, aerial photographs, and satellite images covering the period between 1950 and 2003 to study the city of Muscat in Oman.

In the past few years, significant research has been carried out on the use of satellite data and Geographical Information Systems (GIS) for measuring city growth and sprawl development patterns. Herold et al. (2002, 2003) conducted a comprehensive study on urban land cover dynamics using remote sensing data for the development of spatial (landscape) metrics that were analyzed and interpreted in conjunction with results from the spatial modeling of urban growth. Remote sensing provides spatially consistent data sets that cover large areas with both high spatial detail and high temporal frequency. Dating back to 1960, remote sensing can also provide consistent historical time series data. The importance of remote sensing was emphasized as a "unique view" of the spatial and temporal dynamics of the processes in urban growth and land use change (Dewan and Yamaguchi 2009b; Herold et al. 2003; Boori and Amaro 2010). Satellite remote sensing techniques have therefore been widely used in detecting and monitoring land cover changes at various scales with useful results (e.g., Wu et al. 2013; Stefanov et al. 2001; Wilson et al. 2003; Boori et al. 2010; Muller and Zeller 2002; Weng 2002). Recently, remote sensing has been used in combination with GIS and Global Positioning Systems (GPS) to assess land cover change more effectively than by remote sensing data only (Dewan et al. 2012; Boori et al. 2015a). It has already proved useful in mapping urban areas and as data source for the analysis and modeling of urban growth and land use/land cover change (e.g., Rodriguez-Galiano and Chica-Olmo 2012; Grey et al. 2003; Herold et al. 2003; Wilson et al. 2003).

The objective of this study is to determine the spatial patterns of urban growth over time in Kuala Lumpur. Thus, the growth has been systematically mapped, monitored, and accurately assessed using satellite images in concert with conventional ground data. Mapping provides a "picture" of where growth is occurring, helps to identify the environmental and natural resources threatened by such development, and suggests the likely future directions and patterns of growth. The current study has three specific objectives: (1) investigate the growth of Kuala Lumpur City during 1989-2014 by using remote sensing and GIS; (2) analyze the existence of urban sprawl in Kuala Lumpur; and (3) evaluate current local environmental and natural resource protection and development policies.

\section{Study area}

Kuala Lumpur was chosen as the study area due to its rapid growth. Kuala Lumpur (latitude $3^{\circ} 8^{\prime} \mathrm{N}$; longitude $\left.101^{\circ} 44^{\prime} \mathrm{E}\right)$ is situated in the Federal Territory of Kuala Lumpur in the west Peninsular Malaysia (Fig. 1). The total population of Kuala Lumpur in 2014 is 1.67 million people in an area of $94 \mathrm{~km}^{2}$. This gives the city proper a very high population density of 17,310 people per square mile or 6890 per square kilometer. Greater Kuala Lumpur or the Klang Valley is a large urban agglomeration with an estimated population of 7 million in 2014 with a population density that is nearly equal to that of 


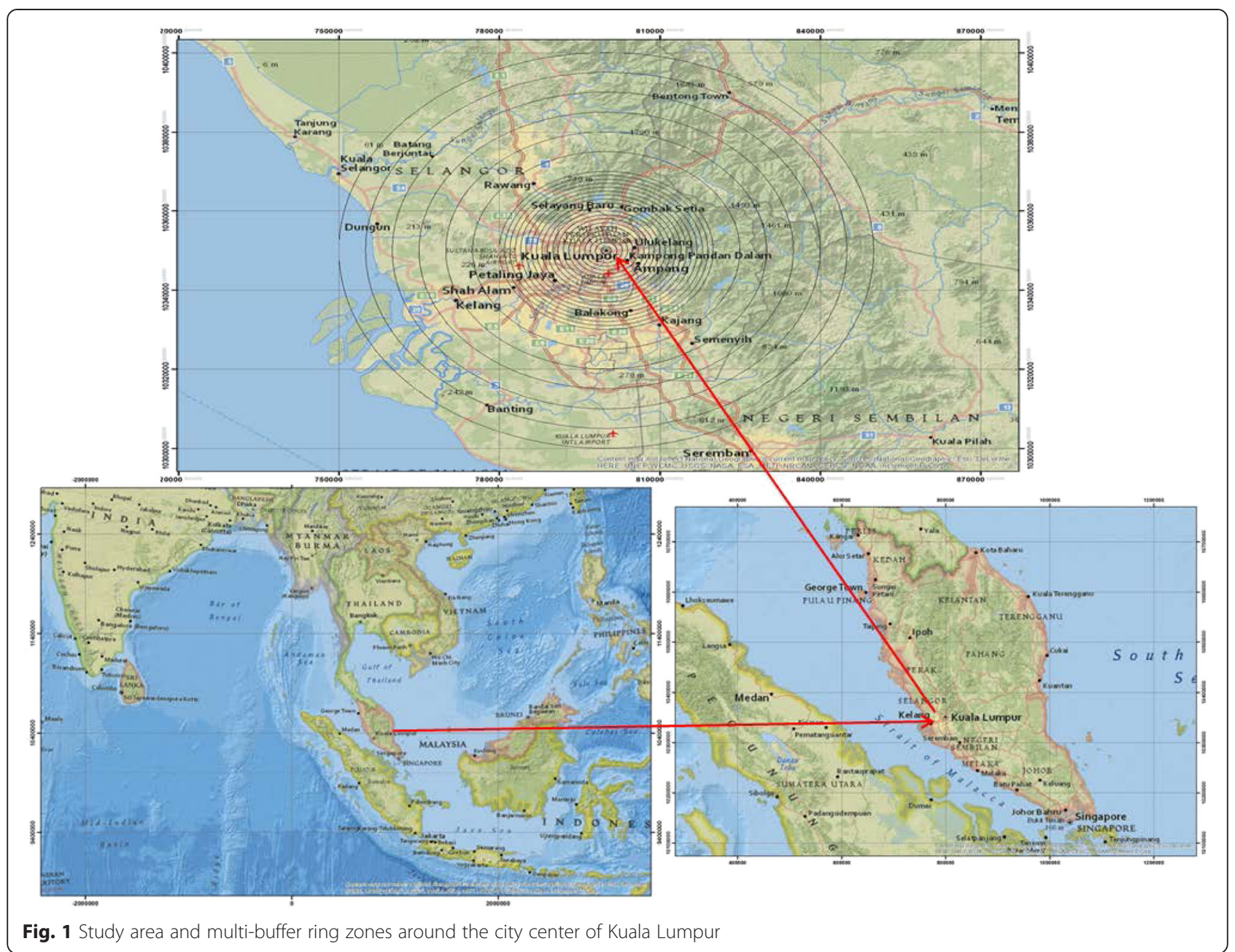

the city proper (City Hall of Kuala Lumpur 2008). According to the 2010 census, major ethnic groups in Kuala Lumpur are as follows: Malays $44.2 \%$, Chinese $43.2 \%$, Indians $10.3 \%$, and others $1.8 \%$. Kuala Lumpur is an aging city as birth rates have fallen in the last decade or two. This has led to a lower percentage of young people under 15, a group that has fallen from $33 \%$ in 1980 to under $27 \%$ in 2000 . The working age group between 15 and 59 has increased from $63 \%$ in 1980 to $67 \%$ in 2000 as more people move to the city for opportunities. By 2020, Kuala Lumpur is projected to have a population of 2.2 million.

The geography of Kuala Lumpur is characterized by the huge Klang Valley. The valley is bordered by the Titiwangsa Mountains in the east, several minor ranges in the north and the south, and the Strait of Malacca in the west. Kuala Lumpur has a tropical rainforest climate, which is warm and sunny, along with abundant rainfall, especially during the northeast monsoon season from October to March.

\section{Methods}

\section{Data}

A selection of multi-sensor and multi-temporal images was used for this study (Ding and Shi 2013; Gamba et al. 2005). The specific satellite images used were Landsat TM for 1989, Landsat ETM+ for 2001, and finally Landsat 8 for 2014, an image captured by different types of sensor. So, three different date satellite images were used with less than $10 \%$ cloud cover. The spatial resolution is $30 \mathrm{~m}$ for band numbers 1 to 5 for all sensors, which is used in this research work. All images were from the USGS website, which is free of cost. All images are radiometric and geomantic corrected. As all images have the same spatial resolution for specific bands, one simply goes through maximum likelihood classification. Here, at least 10 years' time difference was used in two dates' data (Jensen and Im 2007) so that sufficient land use/ cover change information can be investigated (Dewan and Yamaguchi 2008; Anderson et al. 1976). Another reason for selecting these images was their availability. 


\section{Maps processing}

The images obtained as standard products were geometrically and radiometrically corrected by data providers, but, because of the different standards and references used by the various image-supplying agencies, all images were georeferenced again at the pre-processing stage. Then, all three images were geometrically corrected up to the orthorectified level. Images from different sensors have different spatial resolutions. In this study, we preferred to retain the spatial detail, original pixel size, and value of each image for specific bands. Therefore, the images were kept without changing their pixel sizes despite the possible varying accuracy level of classification with the different spatial, spectral, and radiometric resolutions. Next, at the classification stage, a uniform supervised classification was applied on the images. All of the images were classified by creating accurate polygons as training areas for introducing ideal classes for each image separately and by using the maximum likelihood classification method. To create a closer correspondence between the maps produced, the classification was done by only considering four main classes: urban built-up area, agriculture land, forest land (tree/park), and water (Butt et al. 2012; Anderson et al. 1976; Boori and Ferraro 2015). The selected main classes and their descriptions are presented in Table 1.

Post-classification refinement was used to improve the accuracy of the classification. In addition, because the urban surface is heterogeneous with a complex combination of features (buildings, roads, grass, trees, soil, and water), mixed pixels and the salt-and-pepper effect are common problems when using medium spatial resolution data, such as Landsat (Byomkesh et al. 2012; Lu and Weng 2005; Boori et al. 2014c, Thinh 2003). In this step, a $3 \times 3$ majority filter was applied to all the classified land covers (Were et al. 2013; Lillesand and Kiefer 1999).

This research is focused on urban built-up and urban vegetation coverage measurement and their interactions. Rangeland is considered to be both non-urban vegetation and forest area. Furthermore, water bodies have

Table 1 Description of land use/cover classes

\begin{tabular}{ll}
\hline Land use/class & Description \\
\hline Urban or built-up & $\begin{array}{l}\text { Residential, commercial and services, industrial, } \\
\text { transportation and roads, mixed urban and other } \\
\text { urban }\end{array}$ \\
$\begin{array}{l}\text { Agricultural and } \\
\text { vegetation }\end{array}$ & $\begin{array}{l}\text { Agriculture field, small vegetation, sand soils, } \\
\text { landfill sites, areas of active excavation, dry salt flats } \\
\text { Forest or tree/ } \\
\text { parks }\end{array}$ \\
Water bodies & $\begin{array}{l}\text { grass belts } \\
\text { River, permanent open water, lakes, ponds and } \\
\text { reservoirs, permanent and seasonal wetlands, } \\
\text { swamps }\end{array}$ \\
\hline
\end{tabular}

very limited coverage and along with bare land cover are not discussed further in the Results and discussion and Conclusions sections. The maps produced are presented in Fig. 2.

After classification, multi-buffer rings are created for every $1-\mathrm{km}$ distance from 1 to $50 \mathrm{~km}$ from the city center to the outside. Then, the intersection with classified maps for all three dates is performed. Later on, all class areas were measured for 1 - to $50-\mathrm{km}$ distance and derive density according to Eq. 1:

$$
\text { Urban density }=\frac{\text { Settlement area } / \text { ring }}{\text { Total ring area }}
$$

\section{Urban growth rate}

In order to evaluate the spatial distribution of urban expansion intensity, we adapted an indicator called annual urban growth rate (AGR) for evaluating the "urbanization" speed of unit area (Xiao et al. 2006). AGR is defined as Eq. 2:

$$
\mathrm{AGR}=\frac{\mathrm{UA}_{n+i}-\mathrm{UA}_{i}}{n \mathrm{TA}_{n+i}} \times 100 \%
$$

where $\mathrm{TA}_{n+i}$ is the total land area of the target unit to be calculated at the time point of $i+n$ UA $_{n+i}$ and $\mathrm{UA}_{i}$ the urban area or built-up area in the target unit at times $i+n$ and $i$, respectively, and $n$ is the interval of the calculating period (in years). Generally, the target calculating unit is set to the administrative district so as to link with administration or economic statistics. In this research, we preferred the geographical gridding unit since the administrative borders have been changed so frequently in this city. The maps were therefore gridded as $1 \times 1 \mathrm{~km}$ units, and the annual urban growth rates of each unit were then calculated. Lastly, the grid-based annual urban growth rates were mapped to evaluate the spatial features of the "expansion."

\section{Results and discussion}

In this research work, more than 10 samples/training sites have been selected for each class so that classification accuracy is high. The high level of accuracy observed in this study could be the result of the coarse classification since only four classes were used. Furthermore, in all buffer rings, only the urban area was calculated in place of the whole ring. After producing complete land use maps, the total coverage of different classes was determined. Using this information, we calculated the water, forest, vegetation, and built-up area per capita for all the study years (Table 2).

There are several major trends evident in the changes of land cover that are consistent over the period 1989 to 2014. The urban/built-up area increased rapidly, and there was a marked decrease in other classes. The final 


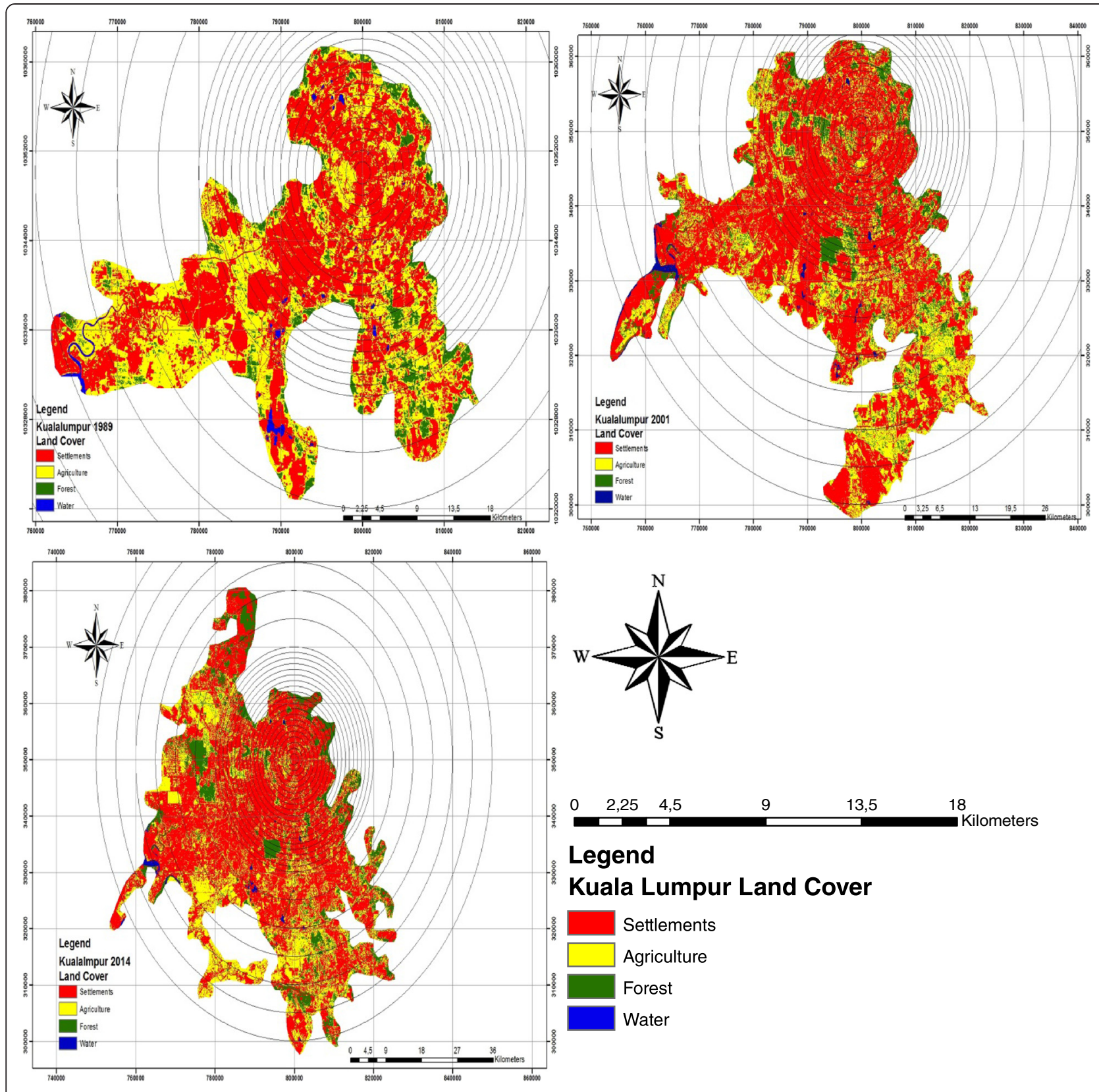

Fig. 2 Multi-buffer ring zones around the city center of Kuala Lumpur for 1989, 2001, and 2014 map

Table 2 Kuala Lumpur land use/cover classes for 1989, 2001, and 2014

\begin{tabular}{lrrrrrr}
\hline Land use/cover & \multicolumn{1}{l}{1989} & & \multicolumn{1}{l}{2001} & \multicolumn{2}{l}{2014} & \\
\hline Settlements & 456.99 & 51.81 & 1098.48 & 60.22 & 1663.23 & 64.36 \\
Agriculture & 345.46 & 39.16 & 520.40 & 28.53 & 699.21 & 27.06 \\
Forest & 70.50 & 7.99 & 188.74 & 10.35 & 209.99 & 8.13 \\
Water & 9.18 & 1.04 & 16.54 & 0.91 & 11.68 & 0.45 \\
Total & 882.13 & 100.00 & 1824.16 & 100.00 & 2584.11 & 100.00 \\
\hline
\end{tabular}

four categories in the land cover maps were forest, urban/built-up, agriculture, and water (Fig. 1). Some interesting patterns in the distribution of dwellings across different buffer zones can be noted in Fig. 1. As expected, the urban/built-up density in Kuala Lumpur tends to decline outward from the city center. According to the land use/cover maps produced for the urban area of Kuala Lumpur City, built-up area was expanded from $456.99 \mathrm{~km}^{2}$ in 1989 to $1098.48 \mathrm{~km}^{2}$ in 2001 and finally reached to $1663.23 \mathrm{~km}^{2}$ in 2014 (Fig. 3). This figure represents $46.67 \%$ growth in built-up area over a period of three decades. In the first decade, urban growth was $35.16 \%$ at 


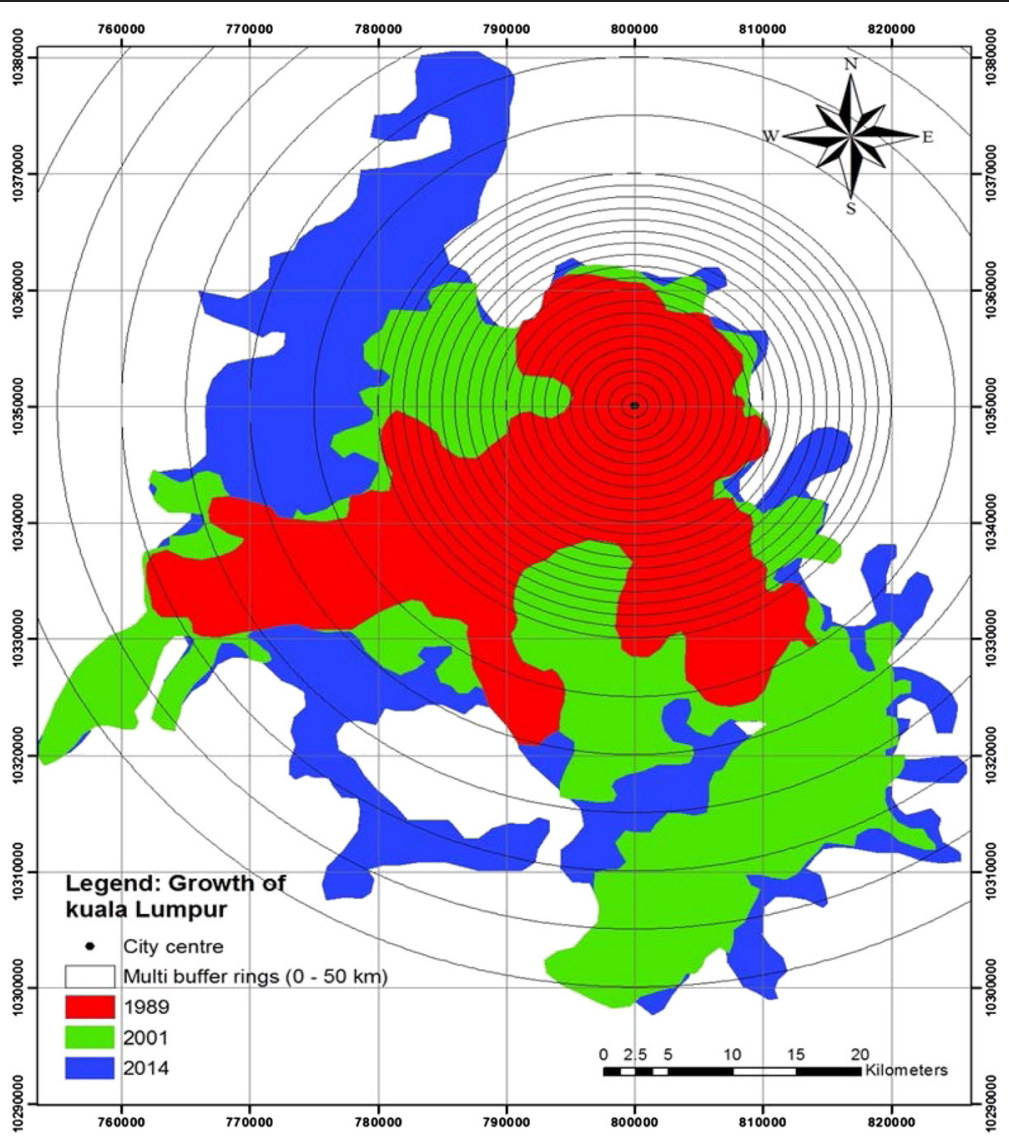

Fig. 3 Growth of Kuala Lumpur in 1989, 2001, and 2014

an average rate of $3.19 \mathrm{~km}^{2} /$ year. In the years 2001 to $2014\left(1663.23 \mathrm{~km}^{2}\right)$, the average rate of expanse was $1.68 \mathrm{~km}^{2} /$ year and totals $21.85 \%$ in the second decade. So, city expanse rate was reduced just half $\left(1.51 \mathrm{~km}^{2} /\right.$ year.) in the second decade. The urban/built-up area has grown by factor 4 over the past three decades, increasing from $51.81 \%$ of the study area in 1989 to $60.22 \%$ in 2001 and finally $64.36 \%$ in 2014, while the area of agriculture land decreased from $39.16 \%$ in 1989 to $28.53 \%$ in 2001 and $27.06 \%$ in 2014. The area of forest has first increased from 7.99 to $10.35 \%$ from 1989 to 2001 and later on reduced $8.13 \%$ in 2014 . In contrast, the area of water was $1.04 \%$ in $1989,0.91 \%$ in 2001, and $0.45 \%$ in 2014 (Table 2).

City density patterns around the city center were also examined to ascertain whether different zones have represented different densities. Figure 4 shows 50 buffer ring zones from 1 - to $50-\mathrm{km}$ distance. It has been argued that the first five zones represent the areas that are within walking distance from the city center. Highdensity development has been supported by the government to encourage people to walk to train stations or other destinations such as shopping centers. This policy has in part been pursued to encourage active transport as part of a healthy lifestyle. We find that in the city center, urban density was more than $90 \%$ for the last three decades. In 1989, it was reduced dramatically around $55 \%$ on the distance of $5 \mathrm{~km}$ from the city center, less than $10 \%$ on $15 \mathrm{~km}$, and $0 \%$ after $40 \mathrm{~km}$. When comparing 1989 and 2014 on the distances of 5, 8, 15, 20, and $30 \mathrm{~km}$, the city density has increased very high. If we compare only 1989 and 2001 on the distances of 8, 15, and $19 \mathrm{~km}$, the city density was highly increased. From 2001 to 2014, on the distances of 4 and $30 \mathrm{~km}$, density was increased. On the distance of $50 \mathrm{~km}$, the city density was $0 \%$ in the last three decades. For the whole three decades, the city density was dramatically reduced on the distance of $20 \mathrm{~km}$ and later on has been stable (Fig. 4).

In 1989 , the city center urban density was more than $90 \%$, the share of agriculture was $10 \%$, and forest and water was $0 \%$ (Fig. 5). Till 4-km distance from the center, the urban/built-up area continuously reduces (55\%) and agriculture has continuously increased till $45 \%$. Later on, both have small variation, and from 8 - to $15-\mathrm{km}$ distance, both classes were reduced. Lastly, both classes were stable or vary a little, and after $40-\mathrm{km}$ distance, both classes have $0 \%$ density. The class forest has 


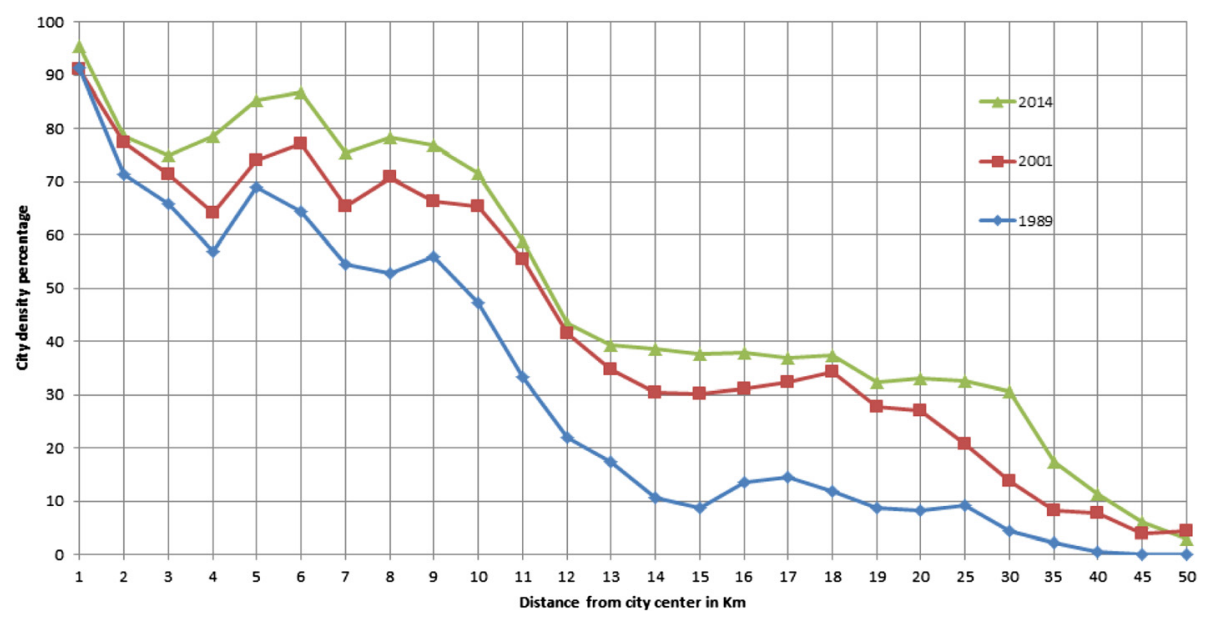

Fig. 4 Kuala Lumpur city density from 1- to 50-km distance for 1989, 2001, and 2014

$0 \%$ density from 1 - to $4-\mathrm{km}$ and from 30 - to $50-\mathrm{km}$ distances. It has less than $10 \%$ density from 5 - to $30-\mathrm{km}$ distance. The water class has almost close to $0 \%$ density in all distances.

In 2001, density of urban/built-up and agriculture is the same like 1989 till distance of $8 \mathrm{~km}$. Later on, urbanization reduces continuously. In 2001, agriculture has $10 \%$ density from 8 - to $50-\mathrm{km}$ distance. Forest has $0 \%$ density on 1 - and 50-km distance. Forest has the highest $15 \%$ density on $9 \mathrm{~km}$ and $10 \%$ density on 7-, 8-, 10-, 11-, 16-, and $17-\mathrm{km}$ distance. Water class was very less on maximum distance and has $0 \%$ density (Fig. 5).

In 2014, in the city center, urban density was more than $95 \%$ and other classes (agriculture, forest, and water) were less than $5 \%$. From 1 - to $3-\mathrm{km}$ distance, urban/built-up areas reduce till $75 \%$, but agriculture increases and reaches up to $22 \%$, and later on reduces or varies around 10 to $15 \%$ in all distances. Urban/built-up density again increases after 3 to $6 \mathrm{~km}$ and later on reduces continuously and reaches $0 \%$ density on $50-\mathrm{km}$ distance. Forest is variant on $10 \%$ and vise versa with agriculture class. In all distances, water is close to $0 \%$ density (Fig. 5).

The census data indicate that the main phase of population growth in Kuala Lumpur occurred between 1989 and 2001. The main causes of this growth were a high birth rate in the early years of the Islamic revolution, rural to city migration, and the merging of nearby villages with the city as it developed (Wikipedia 2014). Urban expansion and subsequent landscape changes are governed by geographical and socioeconomic factors such as population growth, policy, and economic development. In most cases, urban expansion and associated land use/cover changes resulted from a combination of these factors (Wikipedia 2014). For example, socioeconomic policy can strongly affect urban expansion and under the changes driven by urban expansion, the land use patterns of the urban outskirts are altered or adjusted in pursuit of high economic returns (orchards or croplands changing to vegetable land). Even though it is difficult to clarify the influence of these factors in these changes, their influence is examined by analyzing the relationships between developed area (including urban and residential area) and socioeconomic factors such as population, industrialization, traffic conditions, and infrastructure (Wikipedia 2014).

Asia is the most populous and arguably the most vulnerable continent in the world because of the high rate of urbanization and lack of facilities. This variability in Asia has and will continue to impact all sectors, from national and economic security to human health, food production, infrastructure, water availability, and ecosystems. Thus, many large Asian cities have become vulnerable, as more countries are unable to feed themselves and fewer countries produce exportable surpluses (Yin et al. 2011). In Asia, where most of the urban growth has concentrated in metropolitan areas, the problem of basic infrastructure and access is becoming more acute. In these urban centers, uneven distribution of incomes, the prevalence of poverty, diminishing farmlands, inefficient distribution systems, and rising expectations have all contributed to increasingly critical problems, particularly as they affect the urban poor (Dewan and Yamaguchi 2009a). A recent World Bank study maintained that as many as 360 million inhabitants of cities in developing nations suffer from chronic calorie deficits (Wu et al. 2013). Five of every six urban families in India typically spend $70 \%$ of their income on basic needs. Even in relatively prosperous Kuala Lumpur, between 45 and $50 \%$ of total household expenditure goes to basic needs or twice the proportion spent in the UK. Consequently, the lower-income groups in cities 

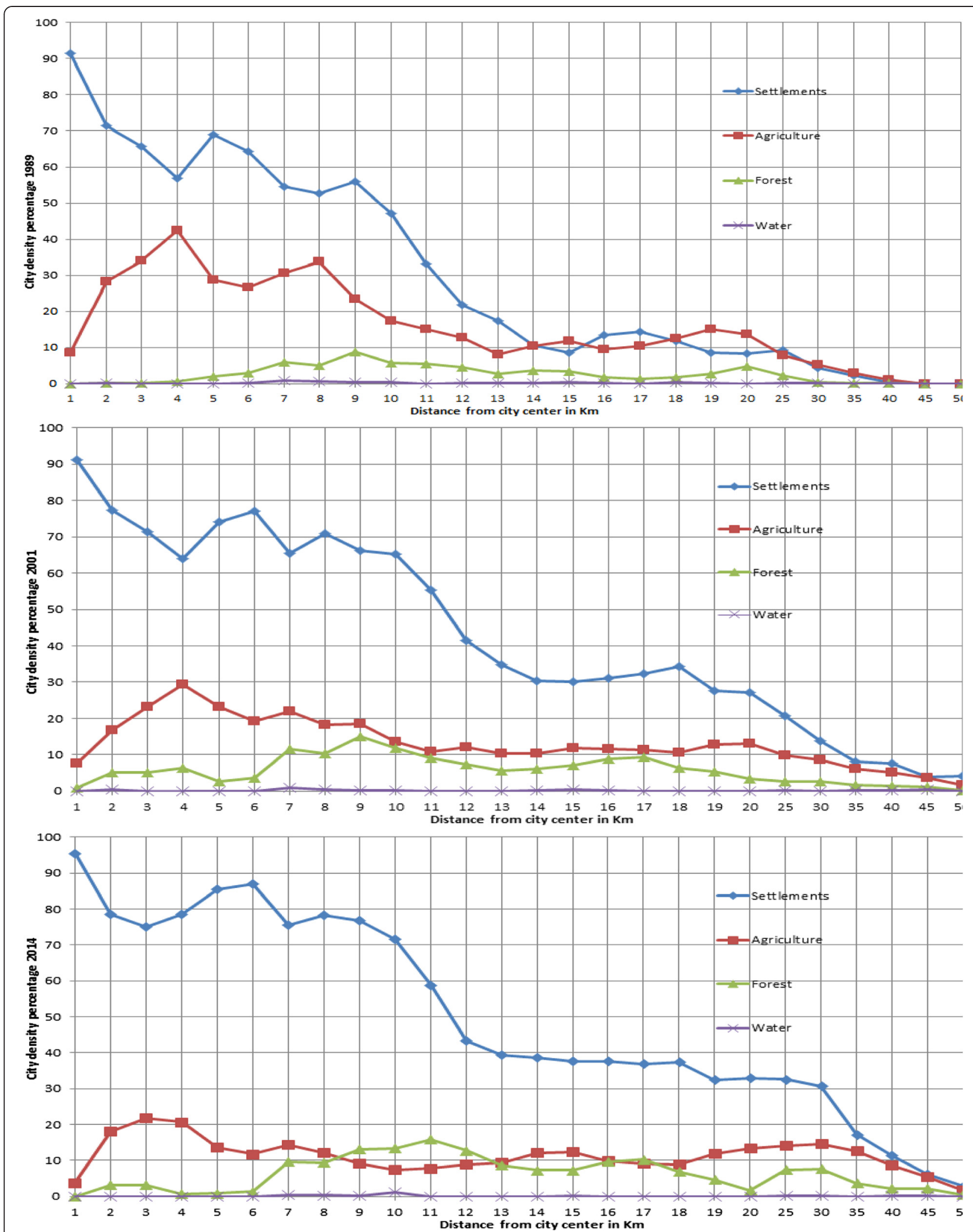

Fig. 5 Kuala Lumpur land cover class density from 1- to 50-km distance for 1989, 2001, and 2014 
of Asia are often worse off nutritionally than their rural counterparts (Dewan et al. 2012).

\section{Conclusions}

Remote sensing and GIS techniques are used to monitor the dynamic phenomenon of urbanization with the help of satellite images and census data for Kuala Lumpur. In comparing 1989 and 2014 on distances of 5, 8, 15, 20, and $30 \mathrm{~km}$, the city density was increased very high. In 1989 to 2001, on the distances of 8,15 , and $19 \mathrm{~km}$, the city density has been highly increased. From 2001 to 2014, on the distances of 4 and $30 \mathrm{~km}$, density has increased and on $50-\mathrm{km}$ distance, the city density was $0 \%$ in the last three decades. In Kuala Lumpur, urban land expansion has largely been shaped by the terrain such as mountains and lakes and social factors such as population growth, migration, and economic development. All open spaces such as gardens and vegetation cover were destroyed and converted to built-up areas; this study demonstrated that development occurred mainly in available open spaces in the city and remaining lands between the buildings. Conversion of vegetation and orchards to built-up area, however, has been a more recent phenomenon. The empirical investigation of urban residential density patterns presented in this paper offers new insights into the spatial implications of policy changes. Analysis has the potential to aid urban planners and policy practitioners in evaluations of urban consolidation or compact city policies.

\section{Competing interests}

The authors declare that they have no competing interests.

\section{Authors' contributions}

MSB did this research work. MN provides guidance and KC help for analysis work. W provides financial support for this research work. All authors read and approved the final manuscript.

\section{Author details}

'Palacky University Olomouc, 17. listopadu 50, 77146 Olomouc, Czech Republic. ${ }^{2}$ Geographical Institute, Ruhr University Bochum, Bochum, Germany. ${ }^{3}$ Samara State Aerospace University, Samara, Russia.

Published online: 04 November 2015

\section{References}

Al-Awadhi T (2007) Monitoring and modeling urban expansion using GIS and RS: case study from Muscat, Oman. In: Proceedings of urban remote sensing joint event, 2007. Paris, France

Alphan H (2003) Land use change and urbanization in Adana, Turkey. Land Degrad Dev 14(6):575-586

Anderson JR, Hardey E, Roach J, Witmer RE (1976) A land use and land cover classification system for use with remote sensor data. US geological survey professional paper, Washington, DC. 964., p 28

Barnsley MJ, Barr SJ (1996) Inferring urban land use from satellite sensor images using Kernel-based spatial reclassification. Photogramm Eng Remote Sens 62:949-958

Boori MS, Amaro VE (2010) Land use change detection for environmental management: using multi-temporal, satellite data in Apodi Valley of northeastern Brazil. Applied GIS 6(2):1-15
Boori MS, Ferraro RR (2015) Global Land Cover classification based on microwave polarization and gradient ratio (MPGR). Geo-informatics for ntelligent Transportation 71:17-37. doi:10.1007/978-3-319-11463-7-2

Boori MS, Vozenilek V (2014) Assessing land cover change trajectories in Olomouc, Czech Republic. Int J Environ, Ecol, Geological and Mining Engineering 8(8):540-546

Boori MS, Amaro VE, Vital H (2010) Coastal ecological sensitivity and risk assessment: a case study of sea level change in Apodi River (Atlantic Ocean), Northeast Brazil. Int J Environ, Earth Science and Engineering 4(11):44-53

Boori MS, Vozenilek V, Choudhary K (2014a) Land use/cover change and vulnerability evaluation in Olomuc, Czech Republic. ISPRS Ann Photogramm Remote Sens Spatial Inf Sci II 8:77-82. doi:10.5194/isprsannals-II-8-77-2014

Boori MS, Vozenilek V, Burian J (2014b) Land-cover disturbances due to tourism in Czech Republic. Advances in Intelligent Systems and Computing 303: 63-72. doi:10.1007/978-3-319-08156-4-7

Boori MS, Vozenilek V, Choudhary K (2014c) Land use/cover disturbances due to tourism in Jeseniky Mountain, Czech Republic: a remote sensing and GIS based approach. The Egyptian Journal of Remote Sensing and Space Sciences 17(3):01-10. doi:10.1016/j.ejrs.2014.12.002

Boori MS, Vozenilek V, Choudhary K (2015a) Exposer intensity, vulnerability index and landscape change assessment in Olomuc, Czech Republic. Int Arch Photogramm Remote SensSpatial Inf Sci XL-7/W3:771-776. doi:10.5194/ isprsarchives-XL-7-W3-771-2015

Boori MS, Netzband M, Vozenilek V, Choudhary K (2015b) Urban growth in last three decades in Kuala Lumpur, Malaysia. IEEE: Urban Remote Sensing Event (JURSE), Joint, pp. 01-04. Doi:10.1109/JURSE.2015.7120536

Butt MJ, Waqas A, lqbal MF, Muhammad G, Lodhi MAK. (2012) Assessment of urban sprawl of Islamabad metropolitan area using multi-sensor and multitemporal satellite data. Arab J Sci Eng 37.1(2012):101-114

Byomkesh T, Nakagoshi N, Dewan AM (2012) Urbanization and green space dynamics in Greater Dhaka, Bangladesh. Landsc Ecol Eng 8(1):45-58

Dewan AM, Yamaguchi Y (2008) Effect of land cover change on flooding: example from Greater Dhaka, Bangladesh. Int J Geoinformatics 4(1):11-20

Dewan AM, Yamaguchi Y (2009a) Land use and land cover change in Greater Dhaka, Bangladesh: using remote sensing to promote sustainable urbanization. Appl Geogr 29(3):390-401

Dewan AM, Yamaguchi Y (2009b) Using remote sensing and GIS to detect and monitor land use and land cover change in Dhaka Metropolitan of Bangladesh during 1960-2005. Environ Monit Assess 150(1-4):237-249

Dewan AM, Yamaguchi Y, Rahman MZ (2012) Dynamics of land use/cover changes and the analysis of landscape fragmentation in Dhaka Metropolitan, Bangladesh. Geo J 77(3):315-330

Ding H, Shi W (2013) Land-use/land-cover change and its influence on surface temperature: a case study in Beijing City. Int J Remote Sens 34(15):5503-5517

Gamba P, Dell'Acqua F, Dasarathy BV (2005) Urban remote sensing using multiple data sets: past, present, and future. Information Fusion 6:319-326

Grey WMF, Luckman AJ, Holland D (2003) Mapping urban change in the UK using satellite radar interferometry. Remote Sens Environ 87:16-22

Herold M, Clarke KC, Scepan J (2002) Remote sensing and landscape metrics to describe structures and changes in urban landuse. Environment and Planning A 34(8):1443-1458

Herold M, Goldstein N, Clarke KC (2003) The spatio-temporal form of urban growth: measurement, analysis and modeling. Remote Sens Environ 86(3):286-302

Jensen JR, Im J (2007) Remote sensing change detection in urban environments. In: Jensen RR, Gatrell JD, McLean D (eds) Geo-spatial technologies in urban environments: policy, practice and pixels, 2nd edn. Springer-Verlag, Heidelberg, pp 7-30

Lillesand TM, Kiefer RW (1999) Remote sensing and image interpretation. John Wiley and Sons, New York

Lu Q, Weng D (2005) Urban classification using full spectral information of Landsat ETM imagery in Marion County, Indiana. Photogramm Eng Remote Sens 71(11):1275-1284

Malaysia (1991) Economic structural change and urbanization.

Muller D, Zeller M (2002) Land use dynamics in the central highlands of Vietnam: a spatial model combining village survey data with satellite imagery interpretation. Agric Econ 27:333-354

Rodriguez-Galiano V, Chica-Olmo M (2012) Land cover change analysis of a Mediterranean area in Spain using different sources of data: multi-seasonal Landsat images, land surface temperature, digital terrain models and texture. Appl Geogr 35(1):208-218 
Saboori B, Sulaiman J, Mohd S (2012) Economic growth and $\mathrm{CO}_{2}$ emission in Malaysia: a cointegration analysis of the environmental Kuznets curve. Energy Policy 51:184-191

Salari HE, Hengsbach T, Henke C, Kopec J, Kozinski M, Sumpelmann P (2013) Detection and analysis of land use changes and growth of Hanoi using remote sensing methods and Landsat satellite images. Technische University Dortmund 2013:01-12

Stefanov WL, Ramsey MS, Christensen PR (2001) Monitoring urban land cover change: an expert system approach to land cover classification of semiarid to arid urban centers. Remote Sens Environ 77:173-185

Thinh NX (2003) Contemporary spatial analysis and simulation of the settlement development of the Dresden city region. 17th International Conference Informatics for Environmental Protection, Cottbus, pp 253-261

Thinh NX, Arlt G, Heber B, Hennersdorf J, Lehmann I (2013) Pin-pointing sustainable urban land-use structures with the aid of GIS and cluster analysis. Sustainability in the information society 15th symposium informatics for environmental protection, metropolis Verlag Marburg., pp 559-567

Weng QH (2002) Land use change analysis in the Zhujiang Delta of China using satellite remote sensing, GIS and stochastic modelling. J Environ Manage 64:273-284

Were KO, Dick OB, Singh BR (2013) Remotely sensing the spatial and temporal land cover changes in Eastern Mau forest reserve and Lake Nakuru drainage basin, Kenya. Appl Geogr 41:75-86

Wikipedia (2014) http://en.wikipedia.org/wiki/Kuala_Lumpur. Accessed date: 09/2014

Wilson EH, Hurd JD, Civco DL, Prisloe MP, Arnold C (2003) Development of a geospatial model to quantify, describe and map urban growth. Remote Sens Environ 86:275-285

Wu KY, Ye ZY, Qi, ZF, Zhang H. (2013) Impacts of land use/land cover change and socioeconomic development on regional ecosystem services: the case of fast-growing Hangzhou metropolitan area, China. Cities 31:276-284

Xiao J, Shen Y, Ge J, Tateishi R, Tand C, Liang Y, Huang Z (2006) Evaluation urban expansion and land use change in Shijiazhuang, China, by using GIS and remote sensing. Landsc Urban Plan 75:69-80

Yagoub M (2004) Monitoring of urban growth of a desert city through remote sensing: Al-Ain, UAE, between 1976 and 2000. Int J Remote Sens 25(6):1063-1076

Yin J, Yin Z, Zhong H, Xu S, Hu Z, Wang J, et al. (2011) Monitoring urban expansion and land use/land cover changes of Shanghai metropolitan area during the transitional economy (1979-2009) in China. Environ Monit Assess 177(1-4):609-621

\section{Submit your manuscript to a SpringerOpen ${ }^{\circ}$ journal and benefit from:}

- Convenient online submission

- Rigorous peer review

- Immediate publication on acceptance

- Open access: articles freely available online

- High visibility within the field

- Retaining the copyright to your article

Submit your next manuscript at $>$ springeropen.com 